\title{
FAMILIAL RENAL DWARFISM
}

\author{
BY \\ STANLEY GRAHAM, M.D., F.R.F.P.S., and JAMES HOLMES \\ HUTCHINSON, M.D., M.R.C.P., F.R.F.P.S. \\ (From The Royal Hospital for Sick Children, Glasgow, and The \\ Department of Medical Paediatrics, Glasgow University)
}

A familial predisposition to arteriosclerosis with secondary malignant nephrosclerosis is well recognized, but that chronic interstitial nephritis may be a familial disease is more debatable, and in children even individual cases are rare. Mitchell (1930), in a comprehensive review of the literature of chronic interstitial nephritis in childhood (renal dwarfism), assessed the number of reported cases under twenty years of age as a little over two hundred, but in view of the recent increased interest in the disease, the number now might well be double this. He quotes eleven instances in which more than one child in the family was affected.

The following report deals with a family in which three and probably four of eight live-born children suffered from renal dwarfism. The first case, Mary B. was seen in 1933, when the diagnosis was established, but not again until she was dying of uraemia in 1938 , when the other members of the family were investigated.

History of pregnancies. Both parents are healthy and now aged forty-four years. No history of kidney disease on either side of the family could be obtained. There have been nine pregnancies, the details of which are as follows :-

(1) John B., born in 1921, died when nine years old of meningococcal meningitis. The mother says he was healthy until the onset of the fatal illness.

(2) Daniel B., born 1922, is alive and well. This boy has not been examined or seen, but the mother reports him well (April, 1941).

(3) Joseph B., born in 1923, died at two years seven months of 'pneumonia.' This illness was associated with coma and rapid breathing, but there was no cough. He was 'always thirsty' and Mrs. B. in the light of what she knows now advances the suggestion that he died of uraemia. (Probable case.)

(4) Mary B. (Case 1), born in 1924, was a renal dwarf and died in 1938. Her case is described in detail later.

(5) Violet B. (Case 2), born in 1928, was a renal dwarf, and died in 1939. Her case is described in detail later.

(6) Twins, born in 1931 .

(a) Patsy B. (Case 3), a renal dwarf, is described in detail later.

(b) Bridget B., alive and well, was examined in April, 1938. At this time, height was $116.5 \mathrm{~cm}$. (average $111 \mathrm{~cm}$.); weight $21.8 \mathrm{kgm}$. $(19.87 \mathrm{kgm}$.$) ; urine normal; non-protein nitrogen 23.8 \mathrm{mgm}$. per cent. The mother reports her still well (April, 1941). 
(7) Miscarriage, 1932.

(8) Bernadette B., born in 1934, is alive and well. When examined in April, 1938, aged three-and-a-half years, height was $93 \mathrm{~cm}$. (average $92.7 \mathrm{~cm}$.); weight $16.32 \mathrm{kgm}$. (15.0 kgm.); urine normal; non-protein nitrogen $20.6 \mathrm{mgm}$. per cent. She is still well (April, 1941).

(9) Miscarriage, 1936.

\section{Detailed case reports}

Case 1. Mary B., born September 22, 1924, came under observation on January 18, 1933, when eight years old because of polydipsia and polyuria (enuresis) of two years' duration. She was healthy at birth, breast fed for nine months, and throve and developed normally. She had measles at five years, whooping-cough at six years, and scarlet fever at seven years. The scarlet fever was not a severe attack and there were said to be no complications. When six years old (i.e. before the scarlet fever) the mother noticed that she was always drinking water and that she had begun to wet the bed at night. She was first seen at hospital on January 18, 1933, and was admitted for investigation.

Physical eXamination. A small, spare child of average mentality; height $114 \mathrm{~cm}$. (average $122 \mathrm{~cm}$.); weight $19.8 \mathrm{kgm}$. $(24.0 \mathrm{kgm}$.). The heart, lungs and abdomen did not show any evidence of disease; the ocular fundi were normal.

INVESTIGATIONS (January, 1933). The urine was pale, specific gravity 1002 to 1007; albumin, a trace on occasions only; no blood; no casts. The output in twenty-four hours varied from 74 to $122 \mathrm{oz}$. The urea concentration test showed 0.92 per cent. urea in the urine two hours after ingestion of $15 \mathrm{gm}$. urea. The phenosulphonephthalein test showed an excretion of only $11 \cdot 2$ per cent. following intramuscular injection of $6 \mathrm{mgm}$. of the dye. Non-protein nitrogen was $62.2 \mathrm{mgm}$. per cent. The blood pressure was systolic $124 \mathrm{~mm}$. Hg and diastolic $92 \mathrm{~mm}$. Hg. Tuberculin skin tests were negative. X-ray examination showed no rickets, but her bones were reported as small.

In April, 1933, she was readmitted and the following findings recorded. The urea concentration test gave 1.78 per cent. in second hour; phenosulphonephthalein test 8.7 per cent. in two hours; non-protein nitrogen $52.6 \mathrm{mgm}$. per cent.; chlorides $325 \mathrm{mgm}$. per cent.; total $\mathrm{CO}_{2}$-combining power (alkaline reserve) 21.5 volumes per cent.; serum calcium $9.8 \mathrm{mgm}$. per cent.; serum phosphorus $6.9 \mathrm{mgm}$. per cent.; haemoglobin 70 per cent. (Sahli); erythrocytes $3,700,000$ per c.mm.; leucocytes 17,300 per c.mm.

Considerable difficulty was experienced in getting the mother to co-operate and she would not allow the child to come to hospital again.

In January, 1938, she was seen by one of us at home in uraemic coma. As she was then too old for admission to the children's hospital (thirteen years three months), she was admitted to an infirmary where she died the next day (January 11, 1938). Permission for a post-mortem examination was not granted.

Case 2. Violet B. was admitted for observation on March 24, 1938, aged ten years. She had been healthy at birth, breast fed and throve well until six years of age (1936) when she had scarlet fever. Since then she had never been well and had become increasingly pale and listless. The mother had regarded her as merely lazy. No history of thirst, polyuria or enuresis.

Physical eXamination. She was a small, spare girl with 'dried-up' appearance. Her complexion was sallow. Genu valgum was present and also slight enlargement of epiphyses at the wrist. Height $112 \mathrm{~cm}$. (average $131.5 \mathrm{~cm}$.); weight $22.56 \mathrm{kgm}$. (29.07 kgm). Examination of the heart, lungs and abdomen did not reveal any abnormality. Her ocular fundi were normal. 
INVESTIGATIONS. The urine showed a low specific gravity (1002), a haze of albumin but no casts or blood cells. Blood pressure was systolic $120 \mathrm{~mm}$. $\mathrm{Hg}$, diastolic $75 \mathrm{~mm}$. Hg. Urea clearance 14.8 per cent.; non-protein nitrogen $100 \mathrm{mgm}$. per cent.; serum calcium $9.4 \mathrm{mgm}$. per cent.; serum phosphorus 5.3 mgm. per cent.; phosphatase 16.8 units (Jenner-Kay method). $\mathrm{X}$-ray examination of bones showed epiphyses wider than normal and changes typical of atrophic renal rickets.

In deference to the mother's wishes she was dismissed from hospital in two days. The mother was instructed to give her sodium bicarbonate 30 grains and calcium lactate 15 grains four times daily along with large doses of a vitamin $A$ and D concentrate ( $\mathbf{4 5}$ drops daily), but it is doubtful if this was carried out. She died at home in Ireland on May 27, 1938, presumably in uraemic coma.

Case 3. Patsy B. was admitted for investigation on February 21, 1938. He was one of twins, healthy at birth and had been breast fed for one month, then on cow's milk. He was normal in size and development at one year, but had congestion of lungs at this time with good recovery. At two years it was noticed that the twin was growing much more quickly and the difference has become more marked in the intervening years. He has always been thirsty and has nocturnal enuresis.

Physical examination. (Aged six years two months.) He was a small but well-covered boy, very dull mentally. Complexion was sallow and waxy. He had slight genu valgum. Height $92 \mathrm{~cm}$. (average $112 \mathrm{~cm}$.): weight $12.74 \mathrm{kgm}$. (20.48 kgm.). Nothing abnormal was found in heart, lungs or abdomen.

INVESTIGATIONS (February 21, 1938). The urine showed a specific gravity of 1008, a haze of albumin but no casts or blood. The blood pressure was systolic $92 \mathrm{~mm}$. $\mathrm{Hg}$, diastolic $40 \mathrm{~mm}$. Hg. Urea clearance $37 \cdot 7$ per cent.; urea concentration test 0.80 per cent. in second hour after $15 \mathrm{gm}$. of urea; blood urea $82.6 \mathrm{mgm}$. per cent.; serum calcium $11.7 \mathrm{mgm}$. per cent.; serum phosphorus 5.0 mgm. per cent.; phosphatase 21.0 units (Jenner-Kay method). X-ray examination showed no evidence of rickets.

- He was dismissed after three days in hospital on alkali, lactate and vitamin concentrate in the same doses as his sister Violet. He was readmitted for three days in June, 1939. Unfortunately the urea clearance figure was not obtained. The urea concentration test showed 0.59 per cent. in the second hour; nonprotein nitrogen $79.3 \mathrm{mgm}$. per cent. The blood pressure was $104 \mathrm{~mm} . \mathrm{Hg}$ systolic and $78 \mathrm{~mm}$. $\mathrm{Hg}$ diastolic. His height had increased $6 \mathrm{~cm}$. and his weight $1.4 \mathrm{kgm}$. in the intervening sixteen months. He is taking the alkali and vitamin concentrate irregularly, and the mother reported (April, 1941) that he was ' well' but still small.

\section{Remarks}

All four cases of renal dwarfism occurred in successive pregnancies in the middle of the mother's child-bearing life. The significance of this is not clear. In the absence of post-mortem examination, no information is available about the underlying pathology. As is usual in such cases, hypertension was not present nor were casts found in the urine. Because of these features it has been suggested that renal dwarfism is more often due to congenital hypoplasia of the kidneys than to chronic nephritis. Coplin (1917) has suggested that the renal hypoplasia might be due to defective arteriogenesis with consequent defective development and scarcity of secretory units. Such an inherent fault in the germ plasm might explain the familial incidence. Congenital cystic disease of the 
kidneys, an even rarer but recognized familial disease, might produce a similar picture but this is unlikely in the absence of palpable kidneys and hypertension.

Chemical poisons, particularly lead, causing chronic nephritis, were considered but with negative results. Infection also might have been responsible, especially infection of the urinary tract. In none of the three cases examined - was there any sign suggestive of this. Nor was there any evidence that syphilis played any part although the Wassermann reactions were not done. The occurrence of the scarlet fever in the first two cases is probably a coincidence. The mother is quite emphatic that in the first case the thirst and polyuria preceded the scarlet fever, and that in the second case, the child's ill-health dated from this illness. The scarlet fever could then be a possible factor in only one of the cases and even in this one it does not seem likely that such a chronic lesion would develop so rapidly after the scarlet fever, although it should be noted that this patient did not give a history of thirst or polyuria, and, incidentally, was the only one who showed signs of renal rickets.

\section{REFERENCES}

Coplin, W. M. L. (1917). Amer. J. med. Sci., 153, 381. Mitchell, A. G. (1930). Amer. J. Dis. Child., 40, 101. 